Jerzy Świeca*

\title{
„Western" Israel in the system of the oriental civilization
}

KEYWORDS: the political system, constitutional conditionings, political arena, the foreign strategy, the demography

StowA KLUCzowe: system polityczny, uwarunkowania konstytucyjne, arena polityczna, strategia zagraniczna, demografia

\section{Systemic and structural-ethnic conditions of external strategy}

A number of analytical works about the origin of the formation of the political system in Israel, also in Polish, have been written so far ${ }^{1}$. In institutional terms, Israel has had a parliamentary cabinet system from the very beginning of the country, although the regime established by David Ben-Gurion has evolved in the direction of deep instability. The collapse of the value system did not take place until 1967, when religious sentiment increased and there was a politicization of non-European immigrants. The Likud Bloc put the issue of the nation before and over class divisions, while the Zionist Labor Party remained the most important idea of the unity of Israeli and Arab middle class. Likud victory would have been impossible without the support of the politicized Sephardic Jews (the Mediterranean Jews) and the Oriental Jews. Socially they were the structure of the impoverished, poorly educated population and they lively responded to populist slogans. On the other hand, the ruling Labor Party bureaucratized well yet functioning democratic system.

Voting attitudes confirm the properties of the so-called oriental revolution. In 1977, only $32 \%$ of the Sephardic Jews supported the Labor Party and as much as $48 \%$ of them

* Associate Professor, Institute of Security and Civil Education, Pedagogical University in Krakow. Mail: jerzyjan2011@gmail.com.

1 See: J. Świeca, Subregion Palestyny. W Poszukiwaniu strategii opartych na rzeczywistości, Katowice 2012, pp. 23-59. 
the Likud bloc 2 . The Mediterranean Jews liked Menachem Begin's charisma and values. On 18 March 1992, the amendments to the constitutional regime were voted and Israel launched a dynamic evolution in the direction of the system which strengthened, already so strong, the position of the prime minister's office. Analysts show that after the 1988 elections 400 thousand immigrants (including 240 thousand from the areas of the former Soviet Union) came to Israel and 240 thousand of them had the right to vote $^{3}$. They also probably determined the fall of the Likud bloc. Immigrants saw the Arab threat, but they thought that it was the result of mistakes and obsessions of the right-wing Israeli government. In Israel, another „revolution” in political thinking and abrupt change in the political option represented by the public took place. Out of 3409 thousand people who had the right to vote more than 10\% (394 thousand) had Arabic origin. Their considerable divisions and left-wing views prevented them from winning more seats ${ }^{4}$. Most of the 150 thousand Arab population of East Jerusalem refused to accept Israeli citizenship, and 1750 thousand Arabs from the West Bank and the Gaza Strip did not have such rights. The key to understand the next „revolution” of voting attitudes was 500 thousand voters voting for the first time (including 240 thousand immigrants $)^{5}$. In Israel eventually a new premier-parliamentary system was established, unique and the only one in the world ${ }^{6}$. This system coincided with elections to the fourteenth Knesset in 1996. Premier obtained the power of „the first over the uneven" and his position corresponded to the role of the British Prime Minister, the strongest in Europe.

There was at the same time, linked to the new regime, system fractionalization, its extreme polarization. In the years 1992-2001, the head of the government in Israel was elected in direct elections, in parallel with the members of the Knesset. The system of direct elections for prime minister did not work, because despite the strengthening of the powers of the head of government, it weakened the two major parties, preventing effective governance. In 2001, the old constitutional provisions were restored and again since 2003 the leader of the victorious party has been appointed the head of government.

2 „The oriental revolution” is widely analysed in: J. Świeca, Regionalne i globalne oddziaływania międzynarodowe $w$ kryzysie bliskowschodnim (1947-1992), Katowice 1993 (especially chapter III subsection 4 „Kryzys w procesie legitymizacji władzy bloku Likud i jego wplyw na stan napięć regionalnych), pp. 95, 103.

3 Keesing's Record of World Events. Weekly Diary of World Events, R. East (edit.), Cambridge, 1992, No 6, p. 38945.

4 See: J. Świeca, Regionalne i globalne..., p. 102.

5 Keesing's..., 1992, No 2, p. 38786.

6 A. Brichta, The New Premier-Parliamentary System in Israel; especialy subsection: "The New Premier Parliamentary System”, „The Annals of the American Academy of Political and Social Science". 01/1998; 555(1):180-192. 
Social and political changes characterizing Israel on the threshold of $21^{\text {st }}$ century threatened Israeli democracy more than the fundamentalist forces. There was fight here between the constitutional law and the law of the Old Testament. The most active and best-organized force was that one moving towards religious fundamentalism. David Ben-Gurion, the founder of the country, the father of Israel, created the bases for such a direction of development. He was the first who suffered the pressure of religious circles while seeking to attain national consensus. He left the case of marital status to rabbinate (in relation to Christians and Muslims - in the hands of their clerical hierarchy). National circumstances were different, however, from today, as the Jewish population did not exceed 800 thousand. There was no question of mixed marriages; they did not implement the term pluralism either. The decision received public approval. The religious camp was divided against itself internally, but very tight against external enemies. The new electoral system has not stabilized Israel. The fragmentation of the political scene is deepening. Formally, Israel is a highly centralized bureaucracy state of hierarchical structure. In fact, the state and its institutions operate on the basis of agreements resulting from the informal arrangements that involve the sharing of power and the process of consultation and negotiation ${ }^{7}$.

Institutional framework, and the demographic-religious scene and ethnic policies of foreign countries may be the right way to explain the external impact of Israel. On 18 December 2003, Prime Minister Ariel Sharon announced the outline of a plan of unilateral separation of Israel from the Palestinian Authority. Statistical data reported that the percentage of the Jewish population in the West Bank in 2003 was 15\% and in the Gaza Strip approx. 1\%. Sharon apparently wanted to join the ranks of the „fathers of Israel", or wash away traces of the drama of the Lebanon war in 1982, of which he had been the initiator and organizer. Reevaluating his attitude towards the idea of maintaining the Greater Israel, he also took into account the evolution of public opinion in Israel, in addition to the economic aspect, the safety and the demographic factor. The right-wing Likud centered around Benjamin Netanyahu attacked Sharon constantly. The support of the Labor Party and Shimon Peres for the group in support of Sharon, and especially his visit to Washington in mid-April 2004, resulted in a political success of the leader of Israel.

At the turn of August and September 2005, Israel carried out the evacuation of Jewish settlements from Gaza and four West Bank settlements. It was basically a onesided action, carried out by Israel forces without the cooperation of Palestinian authorities. It seemed that the foundation for overcoming prejudice, hatred and stereotypes, so important for the peace process, would be erected on a permanent basis and would

7 P. Szatkowska, Kultura polityczna Izraela; [in:] Państwo Izrael. Analiza politologiczno-prawna, E. Rudnik (edit.), Warszawa 2006, p. 49. 
provide a stable situation of the region. Sociology of political parties in Israel points to the instability of the political system. Institutional framework belongs to the most important determinants of external strategy.

The stabilization of the system usually occurs after the euphoria caused by military operations directed against the Islamic organizations of the radical orientation, which use terrorist means. July-August (in 2014) military operation in Gaza raised popularity of Prime Minister Netanyahu to $77 \%$, after which it began declining rapidly to $35 \%$. Benjamin Netanyahu has been a politician for 26 years with extensive decisionmaking experience: he held positions of cabinet ministers for 14 years, he has been the head of government for 9 years, but it is not enough not to make even a blatant political mistakes, risking compromising the interests of the state. He won the elections to the Knesset on 17 March 2015, though with a symbolic advantage, which will not stabilize his continued rule.

Israel itself turned against the West led by the USA, not wanting to give way on Israeli settlers in the West $\mathrm{Bank}^{8}$. In the USA, it came across on a tough opponent that was President Barack Obama, and so the „improved conditions” for Israel ended, in which Israel had acted at times of G.W. Bush's administration, reliable to all expectations of a Tel Aviv. According to Uri Huppert, Israeli far-right parties should be blamed for the weakness of the state apparatus. He is a fierce critic of Orthodox rabbis and their followers, who set Israelis who have non-Jewish mothers on the margins of society. Why are the Orthodox Jews so effective? According to the quoted intellectual and praxeological Jewish activist, coalition governments usually have a slight majority in the Knesset, and small orthodox parties tip the balance. And usually they achieve what they want: a lot of money for religious education and the imposition of religious principles which in a seemingly democratic and secular country should not exist. In the '60s, according to Huppert, Interior Minister Yitzhak Gruenbaum called Israel a democracy ruled by a theocratic law. He was right. Huppert claims that clericalisation supported by right-wing groups exacerbates the conflict with the elementary concepts of a law-abiding state. The result of the game is not yet decided. Will Western humanism or perfidy and slyness rooted in the culture of the Middle East prevail? ${ }^{9}$ Keeping for any price the West Bank will be the end of Israel's democracy (through deprivation of voting rights of the Palestinian minority), approval of bi-national state will mean the end of Israel as a Jewish state ${ }^{10}$.

8 It is the view of Uri Huppert, a prominent journalist and political activist in Israel. See: J. Pawlicki's interview with Uri Hupperte, Newsweek Polska, on 15-21.12. 2014, No 51, pp. 74-77.

9 Uri J. Huppert, Izrael na rozdrożu, Wydawnictwo Edukacyjne „Res Polona”, 2001, pp. 232.

10 A similar view is presented in reviews of books: Y.Elizur and L. Malkin, The War within: Israel's Ultra-Orthodox Threat to Democracy and the Nation, Overlook Press 2013 and A. Pedahzura, The Triumph of Israel's Radical Right, Oxford 2012 - Jeffrey Goldberg. See: J. Goldberg, 
The government, which resigned before the elections, was of a coalition character and Likud's partners were small, centrist parties: Yesh Atid (There is a Future) of finance minister Yair Lapid and Hatnuah (The Movement) of Justice Minister Tzipi Livni, who previously was the leader of Kadima - the party created by Ariel Sharon. Centrist parties were in favor of the creation of a Palestinian state, which the right-wing Likud would not agree with. Benjamin Netanyahu with the support of not only his own Likud, but also the nationalist-religious Jewish Home party of Naftali Bennett, accused the two ministers of trying to make a coup ${ }^{11}$. Although in 2009 Netanyahu supported the idea of a Palestinian state, he was constantly strengthening his position among Jewish settlers in the West Bank, to negate finally the two-state strategy in Palestine. The Prime Minister, who has won poorly in the election, is facing difficult religious compromises, de facto established already by Ben-Gurion, namely revocation of the decision to impose military service for the ultra-orthodox Jews and the abolition of the army for students of religious schools.

The fate of the future coalition will depend on the influential right-wing parties: Yisrael Beiteinu (Israel is Our Home) of charismatic Avigdor Lieberman, and the new party Kulanu (All of Us) of very gifted politically Moshe Kahlon ${ }^{12}$. Although the Israeli parliamentary cabinet system, modeled on the Westminster system, gives the president the minimum powers as the titular head of state, the president Reuven Rivlin, despite being of right-wing provenance, will do everything to prevent Netanyahu to become prime minister. Both politicians are strongly in conflict.

The traditional Labor Party under the leadership of Yitzhak „Bougie” Herzog (Isaac Herzog) leads a joint campaign with the party Tzipi Livni and the center-left coalition has a chance to build a balance power. Israeli Arabs can create the so-called braking block, which will result in the impossibility of governing Israel without their support. The conservative party Likud of Prime Minister Benjamin Netanyahu won the early parliamentary elections in Israel, scoring only 29 seats in the 120 -seat Knesset. The Likud Party is facing now difficult coalition negotiations. This does not mean, however, that the opposition is weak ${ }^{13}$. Led by Isaac Herzog the center-left Zionist Bloc won

Lesser Israel. How Jewish Extremism Threatens Zionism, „Foreign Affairs”, July/August 2013, vol. 92, No 4, pp. 152-158.

11 J. Pawlicki's interview with Uri Hupperte..., p. 75.

12 Ibidem, p. 76.

13 In the elections, Netanyahu's Block won 31 seats in the 120-member Knesset; it suffered significant losses in comparison with previous elections. The good result of the party There is the Future (Yesh Atid), which won 19 seats, turned out to be the big surprise of the elections. The Jewish Home got 12 seats, and 6 was for the centrist party Movement (Hatnuah) of former head of diplomacy Tzipi Livni, who also are to enter the coalition; it is to have a majority of 68 seats. See: In Israel, Netanyahu's party wins but centrists flex muscle, polls show, By Joe Sterling, Sara Sidner and Nicola Goulding, CNNUpdated 1707 GMT (0107 HKT) January 23, 2013http://edition.cnn. com/2013/01/22/world/meast/israel-elections/index.html; access on: 19.03.2015. 
24 seats. The election result of Likud is better than expected, giving the 65-year-old Netanyahu serious chances of the fourth term as the head of government. However, Premier must cope with difficult coalition negotiations. Both Netanyahu and Herzog reject for now the possibility of creating a "grand coalition" of their parties, which Israeli President Reuven Rivlin supports. According to the „Jerusalem Post”, an alliance of the Arab parties with 14 seats will create the third strongest faction in the Knesset. Behind it, there is the centrist grouping There is the Future (Yesh Atid). The party All of Us (Kulanu), seeking a greater social egalitarianism, won one seat less in the parliament. In addition, the religious Zionist Jewish Home party (Ha-Bayit Ha-Yehudi) would get 8 seats, the orthodox groups Shas and United Torah Judaism (Jahadut Ha-Tora) got 7 each, the ultra red-wing Yisrael Beiteinu, referring to immigrants from the former Soviet Union 6, and left-liberal Meretz party 4. The turnout in the elections was 71.8 percent and it was thus the highest since 1999.

At the moment Uri Huppert's words in the summary are very significant: "Although I am a born optimist, I'm afraid of the future. I'm afraid that we will fall into the abyss from which there is no escape" 14 . Although the internal affairs are the most important problem for the pro-Western, and from the political as well as technological and industrial essence western Israel, even though they prove its oriental roots, the regional and local issues determine its future fate in an extremely heavy way.

\section{Palestine and its closest regional environment in the early twenty-first century}

\section{II.1. The war with Hezbollah in Lebanon}

After the withdrawal of Israel from southern Lebanon in 2000, the organization announced its historic victory. In fact, it was theoretically an end to the mission of Hezbollah, which should have disarmed and passed the controlled areas to the Lebanese army. Syria, however, protested ${ }^{15}$. Today, Hezbollah is 10 thousand well-trained and armed fanatics who are going to die reciting the Koran ${ }^{16}$. This is a problem even for the Israeli IDF, considered one of the best armies in the world, representing the highest standards of advanced technology and organizational techniques of the West.

14 J. Pawlicki's interview with Uri Hupperte..., p. 77.

15 P. Salem, The Future of Lebanon, „Foreign Affairs”, November/December 2006, p. 15.

16 R. Ożarowski determines the participation of Hezbollah in the regional conflict as participation in an asymmetric conflict and adds that the asymmetry concerns potentials and methods of operation. See: R. Ożarowski, Hezbollah..., p. 90 et seq.; H. Szafir, Obudzić Szarona, "Wprost" 3.09.2006, No 35, p. 81 . 
A very important turning point for the situation in Lebanon is also the US invasion of Iraq in the spring of 2003. At that time, the political scene of Lebanon polarized in connection with the assessment of the presence of Syrian troops. Premier Rafic Hariri, Druze leader Walid Jumblatt, and many Christian leaders, organized in the anti-Syrian and pro-Western groups, filled the scene. UN Security Council Resolution 1559 of $2004^{17}$ called foreign armies to leave Lebanon ${ }^{18}$. The assassination of Prime Minister Hariri in February 2005 caused an organized, strong public protest and led to the final withdrawal of Syrian troops in April. The anti-Syrian coalition, called The March 14 Alliance, counted on the weakening of Hezbollah and removing the pro-Syrian president Emile Lahoud ${ }^{19}$. It became the opposite: Hezbollah was in the center of the fight against the pro-Western March 14 Alliance. Once Syria was charged by the UN investigation into the assassination of Prime Minister Hariri, Iran cared more direct responsibility for the events in Lebanon. Acting in Lebanon, Hezbollah is evaluated as a force directly linked to the Revolutionary Guards of Iran. Missiles falling on Israel are of Syrian and Iranian origin, and Sheik Hassan Nasrallah, the leader of Hezbollah, takes action after consultations with Iran. Probably hitting of Hezbollah on Israel on 12 July 2006 after the crisis related to the abduction of two Israeli soldiers by the Islamists of Hamas was not consulted with Iran. Another hypothesis is also assumed that Hezbollah rally on 12 July 2006 on the Israeli lands was to involve the southern neighbor in limited border fights and lengthen the process of exchanging prisoners of war at a time when Iran fought against the international pressure on the nuclear program ${ }^{20}$.

The system of Lebanon underwent phases of very effective blocking. The government of Prime Minister Fouad Siniora was based both on the members of the March 14 Alliance and the leaders of Hezbollah and Amal - a Shi'ite group led by the speaker of parliament Nabih Berri ${ }^{21}$. Public opinion quickly switched to the anti-Israel and anti-American option when it turned out that the war of Israel destroyed life and civilian infrastructure. On 26 July the Lebanese government published a draft of 7-point ceasefire, where it should be emphasized, Resolution $1701^{22}$ was built on the same principles. UN Security Council Resolution 1701 called for the cessation of hostilities and the deployment of Lebanese and international forces (UNIFIL), expanded to 15 thousand, south of the river Litani, the introduction of an embargo on the supply of

17 See: United Nations Security Council Resolution 1559, (September 2, 2004), http://www.jewishvirtuallibrary.org/jsource/UN/unres1559.html, 19.03.2015.

18 P. Salem, The Future of Lebanon, p. 16.

19 Ibidem.

20 Ibidem, p. 13. See a wider analysys: R. Ożarowski, Hezbollah..., pp. 96-104.

21 P. Salem, The Future of Lebanon, p. 16.

22 See: United Nations Security Council Resolution 1701 (August 11, 2006), http://www.jewishvirtuallibrary.org/jsource/UN/unres1701.html, 19.03.2015. 
arms to non-state actors, the release of kidnapped on 12 July Israeli soldiers and the withdrawal of the IDF. Moreover, the document urged the Lebanese government to disarm non-state groups and the Secretary General of the United Nations to develop a solution to the Shebaa Farms area, which had been incorporated into the occupied Golan Heights by Israel and to solve the problem of the Lebanese in prisons in Israel ${ }^{23}$. The document was quickly implemented in the deployment of Lebanese and international forces (the latter soon increased from two thousand to ten thousand). Hezbollah as a force participating in the government approved Resolution 1701.

Hezbollah's attacks on Israel had already begun in May 2000, shortly after the withdrawal of occupation forces from southern Lebanon ${ }^{24}$. Every Israeli military movement could cause its international isolation. Why, then, in July 2006, did Israel decide on the operational action? The answer relates to the area of international policy. The government was new (they took power in April 2006) and its three main leaders: Prime Minister Ehud Olmert, Defense Minister Amir Peretz and Foreign Minister Tzipi Livni had no military experience ${ }^{25}$. When on 25 June Hamas kidnapped an Israeli soldier near the border with Gaza, killing two others, soon Hezbollah hit, and its leader Nasrallah linked all the events in one string, announcing negotiations for the release of all kidnapped soldiers. Probably the revealed close ties of Hamas and Hezbollah were the main cause of the new strategy of Israel ${ }^{26}$.

Hamas and its leader Khaled Mashal used the old, inefficient tactic of suicide bombings. The alliance between the two organizations was dangerous for Israel, but the perception of threat was determined by political and strategic culture of the state of Israel. The state of national security can be assessed in each case by four models: 1) as a state of insecurity (the existence of danger) - when there is a large real threat and its perception is correct; 2) there is a state of obsession with danger - when a small threat is perceived as a much bigger; 3 ) when there is a false security state, in which a serious risk is perceived as slight; 4) when there is a security state - when a real, slight threat is perceived properly ${ }^{27}$. In Israel, there was „an obsession with danger”, which resulted from mistakes of the inexperienced government, but also from the troubled regional situation existing since the creation of the state of Israel.

23 See: P. Salem, The Future of Lebanon, p. 17.

24 See: Z. Schiff, Israel's War with Iran, „Foreign Affairs”, November/Dec. 2006, vol. 85, No 6, p. 24.

25 Ibidem, p. 25.

26 Ibidem.

27 This classification is given by D. Frei, Handbook of Foreign Policy Analysis. Methods for Practical Application In Foreign Policy Planning and Bussiness Risk Assessment, Dordrecht 1989; cited from: J. Reginia Zacharski, Strategia bezpieczeństwa narodowego: podejście zintegrowane, ch. 3, [in:] Strategia bezpieczeństwa narodowego Polski, J. Gryz (edit.), Warszawa 2013, p. 76. 
The epitome of this obsession was Sheikh Nasrallah, the first person to planned elimination on the list of chief of the Mossad - Meir Dagan ${ }^{28}$. Israeli generals decided that the elimination of Abbas Mousavi in 1992, the former leader of the Party of God, was a mistake. Nasrallah, his successor, became a much more dangerous enemy. Security Cabinet debated on 12 July, and in the course of the meeting, Deputy Prime Minister Shaul Mofaz (a former defense minister and chief of staff, IDF general) warned that the union of both groups had to be promptly broken, like the ties between Iran and Hezbollah ${ }^{29}$. It was a typical military point of view on issues of national security. They decided on a military strike on a large scale ${ }^{30}$. Mofaz blamed the government of Lebanese Prime Minister Fouad Siniora, in which there were two ministers from Hezbollah, responsible for the attacks of 12 July. He pointed that the report of the United Nations said that the government sanctioned the supply of arms from Syria to Hezbollah and guaranteed the same financial compensation for the wounded fighters from Hezbollah as for soldiers.

Was it possible in this situation to attack the civilian infrastructure of Lebanon? Israel decided on action to halt the supply of military equipment to Iran and Syria, and that meant the bombing of bridges, strategic routes and the airport in Beirut ${ }^{31}$. These were militarized actions and it was extremely important for Israel to limit the objectives of the operation. Civilians were not attacked. Thousands of rockets launched by Hezbollah killed people in Israel ${ }^{32}$. Olmert's government also decided on the limited objectives of the war against Hezbollah. The operation could not bear signs of zerosum game, which indicated a great deal of responsibility and the Western way of thinking and dealing with crises situations. The government described the main objectives as hitting military infrastructure, command centers, operational structures, material resources and the leaders of the movement ${ }^{33}$. Additional objectives were to bring the release of prisoners, the cessation of rocket launches, to force the Lebanese government to take responsibility for the southern area of the state. This time, Israel opted for sending international contingents to the crisis zone.

Israel did not control the carried-out operations. Strategic thinking, common in Western civilization, was weakly present in the Jewish state at that time. The assumption that aviation would perform most of the operational tasks was probably due to the

28 H. Szafir, Obudzić Szrona, p. 82.

29 Ibidem, p. 26.

30 The asymmetry of potential fighting subjects was obvious, but did not prejudge the asymmetry of the conflict. See: R. Ożarowski , Hezbollah..., pp. 104-109.

31 H. Szafir, Obudzić Szrona, p. 26.

32 E.P. Djerejian, From Conflict Management to Conflict Resolution, „Foreign Affairs”, November/Dec. 2006, vol. 85. No 6, p. 42.

33 Z. Schiff, Israel's War with Iran..., p. 27. 
fact that the chief of staff, Dan Halutz, was an aviation officer. As a result, the IDF did not conduct an effective mobilization of reservists, and when it was done, they delayed sending them to the front. Gen. Udi Adam, an "inefficient" commander of the North Caucasus Military District was replaced by Moshe Kaplinsky, the deputy chief of the General Staff. Changing the commanding general during the war in the Israeli army is an event without precedent ${ }^{34}$. In the meantime, on 9 August, The Security Council passed a cease-fire ${ }^{35}$. Chief of General Staff Dan Halutz, despite these decisions believed that the fight must be continued and they must destroy the entire infrastructure in southern Lebanon ${ }^{36}$. In the final phase, Hezbollah launched 200 Katyusha rockets daily to the northern areas of Israel. Israel experienced the effects of damage or loss, and its powerlessness. The final defeat of Hezbollah and destroying the base in Beirut was a partial victory. They killed 400 Hezbollah fighters ${ }^{37}$, while it should be noted that the leadership of the organization survived. They also failed to exert pressure to release imprisoned Israeli soldiers. For the Arabs, Hezbollah gained additional advantages and high prestige. Guerrilla warfare had not been defeated in confrontation with the most powerful army in the Middle East, reflecting the highest standards of the art of war of the West. Did Israel take over the mechanisms of the system imperfections of Oriental Global South in the organization, strategies and advanced technologies, in which it had lasted from 1948 in modern times?

If UNSC resolutions ending the war had been implemented, Israel's situation would have been much better. Resolution 1701, repeating the principles of the previous document (Resolution 155938), called on Hezbollah to disarm and the government of Lebanon to regain sovereignty in the south of the country ${ }^{39}$. Implementation of Resolution 1701 would be very beneficial for peace and for Israel; its realization seems to be impossible. Resolutions of UN bodies are of political and moral as well as legal nature and their implementation can not be translated into sanctions. This weakness of international standards stems from the tradition of the Westphalian order (neoWestphalian), which makes the sovereignty of the state a supreme value.

34 H. Szafir, Obudzić Szarona, p. 82.

35 Z. Schiff, Israel's War with Iran..., p.27.

36 Former Chief of Staff General Dan Shomron noticed that when there is not a political perspective, the armed forces must be allowed to operate, because only a massive military pressure could create a political perspective. H. Szafir, Obudzić Szarona, "Wprost" 3.090.2006, No 35, p. 81-82.

37 Z. Schiff, Israel's War with Iran..., p. 28.

38 United Nations Security Council Resolution 1559 (September 2, 2004), http://www.jewishvirtuallibrary.org/jsource/UN/unres1559.html. Resolution 1559 of the year 2004 defined the standard for international action calling on Syria to withdraw its troops from Lebanon and the disarmament of Hezbollah. See also: E.P. Djerejian, From Conflict Management to Conflict Resolution..., p. 42.

39 United Nations Security Council Resolution 1701 (August 11, 2006), http://www.jewishvirtuallibrary.org/jsource/UN/unres1701.html; Z. Schiff, Israel's War with Iran..., p. 28.

See: E.P. Djerejian, From Conflict Management to Conflict Resolution..., p. 43. 
In this regard, the United Nations should be assessed as an organization with only partially formed culture and strategy of security. As a result, South of Lebanon, the source of the whole crisis, has not been demilitarized. The strength of legal norms and institutionalization of mechanisms for stabilizing would come from the proper scope of the provisions in the agreements. They required, among other things, changes in the qualification of the treaty for an agreement on the final and proper cease-fire, the release of all prisoners and hostages, the commitment of the international community, which would include: economic and humanitarian measures, assistance in the field of security ${ }^{40}$. The strength of Hezbollah in southern Lebanon was, however as a result of Israeli military action, significantly weakened. The action was not so vain and it can be assumed that these objectives were rationally planned.

The war shook the whole Israel, with its central authority situated in the parliamentary and cabinet system, modeled on the Westminster system. People demanded resignation of the management of the government with the Prime Minister. Damages to civilian population were greater than those ones caused in the war of 1948. The same as after the Yom Kippur War and the War of Lebanon in 1982, Israelis demanded the establishment of a state commission to investigate the issue of liability ${ }^{41}$. A shortcoming of these demands was the mechanism of democratic competition, and in connection with that, the possibility of eliminating political rivals by the opposition. Reason of state therefore requires caution and prudence. Before the start of the war the Israelis trusted the IDF and as part of an essential mechanism to ensure safety in case of a unilateral withdrawal of troops. Then that faith was questioned. They even lost confidence in their armed forces. Operational surprise concerned particularly effective antitank defense (antitank missiles), which had created a strong barrier at the moment of the Israeli offensive. This raises the important question of national security: has the power of deterrence of the state of Israel been reduced?

This problem in the context of the statement by President B. al-Assad that Syria can strike on Israel if it does not withdraw from the Golan Heights, and „even the atomic bomb will not save you" 42 , is a confirmation of the assessment made by al-Assad about reducing the deterrence power of Israel. Hitting of especially Israeli air forces was a confirmation of their readiness to repel aggression and great determination. In addition to the real military force, this readiness was an important element in measuring the ability of deterrence ${ }^{43}$.

\footnotetext{
40 E.P. Djerejian, From Conflict Management to Conflict Resolution..., p. 43.

41 Ibidem, p. 29.

42 Baszar al-Asad - cited from: ibidem, p. 30.

43 Ibidem.
} 
Wars rarely follow the assumed scenarios. Hezbollah ended the action with a war on a large scale, in which it won several battles and gained popularity among Arab societies, which, however, devastated the Shiite community representing its political supporters and narrowed its tactical and political option ${ }^{44}$. Controlling Hezbollah with the operating effectively air forces, Israel suffered a defeat in the removal of Islamists from their bases and reducing their activity in firing rockets at the northern part of the state. Failed IDF operations undermined the prestige of the invincible army of Israel ${ }^{45}$. Israel, redefining its safety priorities, for the time first evaluated the nuclear potential of Iran as a major threat ${ }^{46}$. In the region, Iran was the axis of the Oriental system in the radical Shiite variant. Anti-Iranian obsession would then grow in Israel, until after 2015, when at the beginning of March, speaking in both connected chambers of the US Congress, Prime Minister Benjamin Netanyahu expressed his perception of supreme, obsessive in perception, threats by Iran. Palestinian terrorism was also treated with extraordinary attention. Neutralization of the Iranian threat requires political and military means. Israel is not alone. It can count on the United Nations personifying the international community and mainly the US and the Western system. President Barack Obama is anyway seeking an agreement with Iran, hoping that the country does not develop a nuclear program for military purposes.

In terms of the military means, the state of Israel, according to part of the leadership elite of Israel, should develop „second-strike capability” against Iran ${ }^{47}$. It would require a settlement of the crisis in the sub-region of Palestine, because the pressure from this area is an additional threat and fight on several fronts would be the usual scattering of forces. A clear buffer zone between Iran and Israel is needed, and it may be a neutralized Syria, with which they need to settle contentious issues ${ }^{48}$. Syria, however, has its serious internal problems, and in fratricidal fighting, which erupted in early 2011, over 200 thousand people lost their lives to spring 2015.

The highest price in the war in 2006 was paid by Lebanon, which became the scene of a regional war, the most devastating in recent history of the country. The final victory of peace means, UNSC Resolution 1701, could lead to political transition and security in the region. This model can be used to resolve other regional conflicts with the multilateral rule ${ }^{49}$. Assessments of the war were varied. Hezbollah leader Sheikh Nasrallah announced the spiritual victory of the Islamic movement. The war did not end with the

44 R. Ożarowski analytically explains the asymmetry in the activities of the Party of God. See. R. Ożarowski, Hezbollah..., p. 109-121; P. Salem, The Future of Lebanon..., p. 13.

45 Ibidem, p. 13.

46 See: Z. Schiff, Israel's War with Iran..., p. 31.

47 Ibidem.

48 Ibidem.

49 The opinion from: P. Salem, The Future of Lebanon..., p. 14. 
triumph of Israel as the previous ones. Hezbollah gunners stopped armored units of Israel and its elite forces ${ }^{50}$. These opinions were confirmed by television reports showing the defeated and demoralized soldiers returning from the front line. They destroyed dozens of Merkava tanks that were legendary military technology of Israel ${ }^{51}$.

The triumph of Hezbollah was celebrated throughout the Arab and Muslim world. The price for the victory of Lebanon, especially in its southern part and the southern Shiite Beirut was clearly visible. 1200 civilians (including $1 / 3$ children) were killed, 4,000 were injured and 1 million was away from home to escape the army. Material damage included 130 thousand houses, thousands of small businesses and hundreds of roads, 300 factories, 80 bridges, many schools, hospitals, energy grids ${ }^{52}$. They were much heavier damages than during the invasion in 1982. Economic losses were estimated at $\$ 7$ billion i.e. 30\% of Lebanon's GDP. Hezbollah also suffered strategic-military and tactical losses. It lost control of the south of the country and points on the Syrian-Lebanese border, from where they had received equipment. About 600 elite Hezbollah shooters were killed and a number of medium and long-range launchers were destroyed ${ }^{53}$. The war undermined the impression (stereotypes) that Nasrallah was so intelligent and responsible not to expose Lebanon to devastating attacks. The Shiite community noticed that neither Syria nor Iran had rushed to their aid. In addition to losses there is hope in the form of implementing the system of the UN resolutions. With the help of the program expressed in them, they can consolidate security, rebuilding and reconstruction of the economy and political development. Iran and Syria have approved Resolution 1701 and the multinational UNIFIL (they come in large part from China, France, Germany, Italy and Turkey). The resolution does not introduce a mechanism of disarmament of Hezbollah, and this is the most serious issue ${ }^{54}$. So much depends on Iran sponsoring Hezbollah. In case of creating a demilitarized buffer zone south of the river Litani, Israeli attacks would be meaningless.

Of course, the matter of reconstruction, rebuilding and economic development, is no less important than military issues and direct security means. Initially, Hezbollah declared participation in the refinancing of these programs, but the cost exceeded its possibilities. Probably the government of national unity, for which Maronite leader Michel Aoun calls, would be a good solution stabilizing the system of government of Lebanon ${ }^{55}$. Such a consociational system filled with consensual mechanisms saves

$50 \quad$ Ibidem, p. 18.

51 See more about the origins of technological construction of Merkava tank: S. Weiss, Merkawa znowu zwycięży, "Wprost" 21.01.2007, No 3, p. 91.

52 P. Salem, The Future of Lebanon..., p. 18.

53 Data cited from: ibidem.

54 Ibidem, p. 19.

55 Ibidem, p. 21. 
the country from the deepest crises, consolidating the institutions of government and society ${ }^{56}$. Relations with fundamentalist Iran are becoming particularly important. The ambitions of the Ayatollahs led to a radical reevaluation of Israeli-Arab (mainly Israeli-Saudi) relations. The objectives of the Saudi monarchy were limited in the past to stabilize the Middle East, the end of the conflict between Israel and the Palestinians, neutralizing Saddam Hussein's Iraq, and keeping the royal family far from the upheavals ${ }^{57}$. Perhaps the new monarch of the Saudi state, from 23 January 2015 with the death of his brother, King Abdullah bin Abdulaziz Al Saud, Salman bin Abdulaziz Al Saud, who started his reign as the seventh ruler of Saudi Arabia, will be continuing the strategy of monarchic family.

For Israel, the atomic threat had arisen from the Shiite Iran, and Israel itself was forced to build a coalition with a part of the Arab regimes, the Islamic countries, heavily modernized and even partially Westernized. Israel became a natural ally of the Saudis because of their determination in security issues. Mass media informed the public opinion of Israel that Tel Aviv had obtained the consent of moderate Arab states (Saudi Arabia, Oman, the United Arab Emirates and Jordan) to use their military infrastructure in the event of an attack on Iran ${ }^{58}$. In late March 2015, the Saudi air force with the support of the American bases finished intensive operations against terrorists in Yemen.

Only a complete withdrawal of Iran from nuclear program can protect it from Israeli air raids. A long-term negotiated framework agreement $5+1$ of world powers with Iran was summarized on 2 April 2015 in Lausanne ${ }^{59}$. It announces the signing of the full treaty on 30 June. Iran would eliminate $2 / 3$ of 19,000 centrifuges enriching uranium and the reactor allowing the construction of a plutonium bomb. The differences between the English and Iranian texts ${ }^{60}$ raise doubts, which is not a good sign for an effective and final agreement.

Is Israel, if it decided on the military attack, able to win such a confrontation even if only from a military point of view? The State of Israel has 250 nuclear bombs and

56 More about the consociational system: J. Świeca, Wspótczesne systemy demokratyczne, part I: Wybrane zagadnienia z problematyki wyborczej oraz makroananlizy systemowej w ujęciu porównawczym, CAN, Kielce 2003, p. 17-22.

57 H. Szafir (z Jerozolimy), Koalicja czerwonego guzika. Tajna oś obronna Izraela z umiarkowanymi państwami ararbskimi, "Wprost" 18.03.2007, No 11, pp. 96-97.

58 Radio station Kol Israel reported the information, bypassing the military censorship. Shortly thereafter, Al-Jazeera also informed about it. In the following days, meetings were held between the heads of interviews of both parties. Many Muslim non-Arab countries (probably Turkey and Asian countries of the former Soviet Union) has granted Israel support „towards Iran.” cit. after: ibidem, p. 97.

59 See: The truth about Iran nuclear deal - http://www.ncr-iran.org/en/?gclid=Clecw4KY5MQCFRHHtAodwV0AOQ, 5.04.2015.

60 Ibidem. 
missiles and submarines (mainly from Germany and purchased on very good terms of long-term lending), equipped with missiles capable of carrying nuclear warheads. In a secret agreement between Nixon and G. R. Meir in 1969, it was stated that as long as Israel would not demonstrate possession of weapons of mass destruction and would not conduct any official nuclear tests to the public, the United States would tolerate its possession and protect the entire program ${ }^{61}$. In Israel, they treat nuclear vagueness and ambiguity as a strategic and diplomatic victory. Today, however, public awareness around the world disapproves possession of weapons and supports the creation of zones free from mass destruction. Nevertheless, in the US strategic terms, Middle East and South Asia are the regions in which not one but three countries have nuclear weapons (Pakistan, India, and Israel). It is widely believed that the use of " $\mathrm{N}$ " arms by Israel would only be possible in a situation threatening the destruction of the state, but at the same time it is emphasized that confidence to Tel Aviv would increase in the international arena if the fact of having the arsenal was revealed ${ }^{62}$. In fact, the lack of clarity on this issue prevents Israel from implementation of its national interests. In the sphere of negotiations on arms control or disarmament, Israel is isolated due to the lack of clarity, clarity to the possession of nuclear weapons. In the $50 \mathrm{~s}$ or $60 \mathrm{~s}$, possession of „N” arms was justified by security, but today it makes Israel unable to achieve the political and diplomatic objectives. Israel destroys its image as a democratic, responsible state although it is not a party to the NPT ${ }^{63}$. The ambiguity in terms of having / not having nuclear weapons by Israel undermines the need of the state to inform of the issues decisive of citizens' life and death ${ }^{64}$. Israeli scientist Mordechai Vanunu, who in 1986 revealed details of Israel's nuclear assets, estimated that such a powerful arsenal was short of the officially proclaimed doctrine of „ultimate, defense applications"65. Israel should adjust its strategy and political praxeology to the new regional environment in which Iran will play an increasingly important role.

The fact is that moderate Arab states formed the defensive axis, which directs the Arab quartet composed of Egypt, Jordan, Saudi Arabia, UAE, in the event of an Iranian nuclear attack, which is not currently possible as a strategic option of Tehran ${ }^{66}$.

61 The information was revealed in 1991 by Israeli journalist Aluf Benn, and H. Kissinger in his memoirs about the meeting Nixon-Meir. See: A. Cohen, M. Miller, Bringing Israel's Bomb Out of the Basement. Has Nuclear Ambiguity Outlived Its Shelf Life?, „Foreign Affairs”, September/October 2010, vol. 89, No 5, p. 31.

62 The opinion was expressed by authors of Reducing Nuclear Danger: US Admiral W. Crowe, McG. Bundy and S. Drell. Cit. after: ibidem, p. 36 et seq.

63 Its art. 6 also assumes liquidation of the nuclear arsenal. Ibidem, pp. 37-38.

64 Ibidem, p. 39.

65 „defensive last resort”. These resources were to include: atomic bombs and missiles, thermonuclear, neutron artillery shells, a total of several hundred units. Ibidem, p. 40.

66 Information taken from sources close to the military intelligence of Israel - Aman. Ibidem, p. 97. 
A prominent Iranian dissident intellectual - Maziar Bahari - believes that Tehran with supreme leader Ayatollah Khamenei, and from 2013 the new, moderate president Hasan Rouhanim will act pragmatically ${ }^{67}$. There is also a clear asymmetry of potentials: small Israel has 250 nuclear warheads, and Iran having great raw material potential, 80 million population, vast territory, can not produce a single nuclear bomb.

The authorities in Beirut declare a neutral stance towards the long, bloody internal conflict in Syria, but the Lebanese Shiite group Hezbollah sends its fighters there to help the Alawitic regime of President Bashar al-Assad in the fight against Sunni rebels. Both Assad and Hezbollah have the support of Shiite Iran. The so-called Islamic State (PI), formerly the Islamic State of Iraq is a Salafist terrorist organization, and self-styled caliphate announced in 2014, on the territory of Iraq and Syria ${ }^{68}$, exacerbate existing problems and are a threat to Israel's security. The aim of the group is to establish hierocracy based on the principles of Sharia (Koranic law), on the territory of Iraq, Syria and Lebanon. On 29 June 2014, the group proclaimed foundation of the Caliphate under the name of "Islamic State" in the occupied territories. It was estimated that the group in August 2014 brought together 80 thousand militants, including 50 thousand fighting in Syria and 30 thousand in Iraq. Islamic State led an active recruitment campaign among supporters of jihad and caliphate. Therefore, many Muslims residing in European countries, the United States and Australia fought in their militia. After the expansion of the Islamic State in Syria and Iraq and committing crimes against the civilian population, the United States intervened with air strikes against jihadists in Iraq on 8 August 2014. Then, after the announcement of „Obama's strategy” and the formation of the international coalition, they extended the air operation to Syria on 23 September 2014.

In Lebanon, which is still trying to return to the political balance after the 15year civil war, there are clashes between factions loyal to both sides of the Syrian conflict, as well as rebel attacks on the army and cross-border military actions of Syrian Islamists. As it is suggested, the army is one of the few state institutions whose activities the religion division of Lebanese into Christians, Sunnis and Shiites does not paralyze. The intention of Saudi Arabia, involved in air strikes on Islamists in Syria, may be to strengthen the Lebanese army as a counterweight to Hezbollah. France pledged in October 2014 to supply Lebanon with weapons worth $\$ 3$ billion. Deliveries will be financed by Saudi Arabia.

67 The interview in Newsweek Polska, 13/2015, 23-29.03.2015, pp. 62-63.

68 Extensive analysis of the structure, which despite appearances is not like al-Qaeda - though uses terrorist methods, is carried out in: A.K. Cronin, Why Counterterrorism Won't stop the Latest Jihadist Threat, „Foreign Affairs”, March/April 2015, vol. 94, No 2, pp. 87-98. 
French deliveries will be allocated to the Army, Air Force and Lebanon Navy. Balancing the hard power of the Islamic State in Syria and Iraq and its allies in the form of Hezbollah, al-Assad's regime in Damascus, and mainly Iran, naturally strengthens Israel's security. It is also a confirmation of the thesis that cooperation of Israel with part of the Arab countries in the field of security strategy is possible.

The issue of relations with Iran breaks the relationships of President Barack Obama with Prime Minister B. Netanyahu. Netanyahu criticized this topic of Washington strategy to Tehran in his speech on 3 March 2015, where he was invited arbitrarily by the leader of the Republicans in the House of Representatives - John Boehner. 94\% of American Jews live in 13 key districts, so they can decide the success of the Republicans in the presidential election. It should be noted that in the electoral program of the Democratic Party from 2012, there has been a provision that „Jerusalem is and will remain the capital of Israel" 69 . In the US there is a mosaic of ideologically diverse and openly operating pro-Israeli organizations, mostly Protestant, and the Protestants represent $60 \%$ of the US population (Jewish population only $2 \%$ ). However, the awareness of the significance, consensus and strategic location in terms of Israel's Jewish electorate has influence on the decisions of politicians ${ }^{70}$.

\section{II.2. Israel's war with Hamas in Gaza. The geopolitical dimension of the conflict}

The end of December 2008 confirmed the dramatic opinions: 205 people were killed and more than two hundred were injured, most of them seriously injured in a series of attacks of air forces of Israel on 27 December on the Gaza Strip - according to the Qatari station Al-Jazeera, pleading for medical source on site ${ }^{71}$. It was the largest air strike since Israel's war in $1967^{72}$, with the F-16 and fired missiles. Its cause could be the fact that Hamas ruling for 1.5 years in Gaza had rejected, a few days earlier, extending the half-year truce, which was just to expire. It seems that the whole situation was also conditioned by the circumstances of the pre-election in Israel and a severe systemic crisis. Political leaders competed in ideas to achieve a higher level of security to gain electoral support. The war was seen mainly as an activity of the defense minister

69 See: P. Milewski, Amerykańscy przyjaciele Izraela, „Newsweek”, 10/2015, 2-8.03.15, pp. 51-53.

70 Ibidem, p. 53.

71 Jihad: it was a massacre - there will be retaliation, http://wiadomosci.wp.pl/ gid,10700148,title,Gaza-plonie,galeria.html?ticaid=17379, 27.12.2009.

72 Israel and Gaza,The air war continues, Dec 28th 2008 | JERUSALEM, From Economist. com, Israel continues its assault on the Gaza Strip, killing over 280 people, http://www.economist. com/world/mideast-africa/displayStory.cfm?story_id=12844105\&source=features_box_main, 27.02.2015. 
and Labor Party leader Ehud Barak, who was still losing in the polls with the Foreign Minister, Mrs. C. Livni and the head of the opposition Likud B. Netanyahu.

For a long time rockets falling on Israeli territory were fired from the area of the Gaza Strip. These actions, in turn, were conditioned by Israel's blockade of humanitarian aid for Gaza, where more than one million Palestinian residents experienced a severe humanitarian crisis. Air Force attack on the area of Gaza was an asymmetrical reaction, which could not get the approval of world public opinion. There were massive anti-Israel demonstrations in Jordan, Lebanon, and Iraq. The Security Council on the night of 27 and 28 December called on the parties to stop the violence. Unfortunately, the spiral of hatred and fighting spirit was growing on both sides of the conflict. Israelis army began to approach the borders of the Gaza Strip. During the first days the attack developed by the logic of aircraft strike.

In Israel, fear was still growing that Hamas's rockets could threaten top-secret Israeli nuclear object in Dimona in the Negev Desert ${ }^{73}$. The British journal Time emphasized that Israeli commanders were shocked by the scale and modernity of the Hamas arsenal. The shock meant that the underestimated subjective side of perception of danger prevailed in the circles of Israeli strategists. In Israel, they pointed out that the purpose of raids on facilities in the Gaza Strip was to deprive Hamas of attacking opportunities with new missiles Grad. The missiles were smuggled into Gaza by sea and through tunnels, replacing homemade rockets known as Kasam. Representatives of the Israeli authorities also claimed that Hamas came into possession of dozens of Iranian missiles Fajr-3, whose range is even greater. Many Israelis feared that Dimona would soon be within Hamas rockets. British newspaper wrote, "It is believed" that Israeli nuclear warheads are stored in Dimona. Israeli authorities have consistently refused to answer the question of whether it is true that the Jewish state has nuclear weapons ${ }^{74}$.

It can be considered that starting a war with Hamas on 27 December 2008, Israel was provoked, but just as in Lebanon in 2006, this war was also hard to complete, as well as validate ${ }^{75}$. The scale and brutality of the war was scary. However, starting the war to prevent rocket fire by Hamas was the right decision. Only after 19 December, when Hamas decided not to extend the 6-month-old truce, and till 27 December, the

73 According to 'Times", cited from: http://wiadomosci.wp.pl/kat,1356,title,Times-supertajny-izraelski-magazyn-rakiet-nuklearnych-w-zasiegu-rakiet-Hamasu,wid,10714161,wiadomosc. html?ticaid=1740b, 02.01.2009.

74 See: A.Cohen, M. Miller, Bringing Israel's Bomb Out of the Basement, „Foreign Affairs”, September/October 2010, vol. 89, No 5, pp. 30-44.

75 Israel's war in Gaza, Gaza: the rights and wrongs, Dec 30th 2008, From The Economist print edition, http://www.economist.com/printedition/displayStory.cfm?Story_ID=12853965, 27.02.2015. 
date of commencement of hostilities, they fired 300 rockets. Up to this point, the justification of Israeli attack with provocation is logical and legitimized.

Every war must go through three tests to be considered as justified ${ }^{76}$. First, the state must exhaust all other means of defense. Second, the attack must be proportionate to the degree of danger and thirdly, it must provide an opportunity for achieving the objective. Israel had no strong arguments in any of these tests. Although it was provoked, Hamas underwent the same provocative violence. Israel used the economic means, using the economic blockade of Gaza, and even the blockade of humanitarian aid. If the blockade had been lifted, Hamas would have prolonged the truce ${ }^{77}$. Resuming the firing of rockets, Hamas sought a truce on the new conditions, including the opening of the borders.

It was in the interest of Israel, the state of the western political system and system modeled on western standards, to minimize casualties on the civilian side. Another test concerns effectiveness. At the beginning, they declared the destruction of Hamas, but operations since the beginning of 2009 had a character of a different implemented objective: „to change the existing realities"78. The fights strengthened Hamas's position in their society, like Hezbollah in 2006. So we can ask the question: was the action against Hamas to compensate for the failure of the fighting with Hezbollah? Achieving the cease-fire was extremely difficult and required a mediator, and President Obama did not yet enter his office at the beginning of the war (in 2006 radical and forever proIsrael Bush behaved passively hoping for instant success of Israel). Probably without the blockade of the Gaza, nothing could change, and its abolition would lead to positive dynamics of events.

The UN Security Council on 8 January passed a resolution calling on the parties to cease hostilities and Israeli withdrawal from the Gaza Strip ${ }^{79}$. Earlier, on 6 January, President H. Mubarak repeated Sarkozy's calls for cease-fire, which was interpreted as his consent to cooperate with the USA actions on creating regime of open borders (the rules of crossing them) that would satisfy Israel. Any adjustments even just partial were extremely necessary, because constituted a hope for a better tomorrow. The war in fact resulted in not only the phenomena associated with pacifism, but it also abounded in the crimes and caused a humanitarian crisis.

76 Ibidem.

77 Ibidem.

78 Ibidem.

79 United Nations Security Council Resolution 1860 (January 8, 2009), http://www.jewishvirtuallibrary.org/jsource/UN/unres1860.html, 10.03.2015. The attitude of the US delegation was Outstanding. They abstained from voting and did not exercise their right of veto. There were 14 votes in favor of the document. 
On 18 January, Israel and Hamas separately declared a cease-fire in the 3-week war (22-day) that had claimed more than 1,200 deaths (at least half of them civilians) on the Palestinian side. The position of Hamas was a response to the peace efforts of Egypt. On 19 January in the resort of Sharm el-Sheikh, the leaders of France, Germany, Great Britain, Italy and Spain gathered to support Egypt's efforts aiming to stop the flow of arms across the border to the Gaza Strip ${ }^{80}$. The meeting took place after Israel and the US signed on 16 January in Washington a Memorandum of Understanding (C. Rice C. Livni) which assumes the US cooperation with Israel, Egypt and other countries in order to interrupt the flow of arms from Iran to the Gaza Strip.

According to the president M. Abbas, reconstruction of the Gaza Strip by the West is not a matter of humanitarian aid, but the political and strategic goal ${ }^{81}$. Not all the Israeli public supported the war. The left-wing Meretz party objected the aggression. Haim Orion, the party leader, stated that if the war lasts, „we can overcome the limits we imposed on ourselves" 82 .

The destruction of the Gaza Strip, according to Palestinian estimates, exceeded the amount of $\$ 2$ billion, and the 3-week aggression brought even 1,300 fatalities ${ }^{83}$. The cruelty of this and every war was palpable. The divisions between the Palestinian factions deepened ${ }^{84}$. While the political „center” in the Fatah and Hamas was willing to talk about the government of national unity, the extreme groups proved to be radically confrontational.

The Arab world was subdivided even more: on the one hand, Egypt, Jordan, Saudi Arabia and on the other one radical countries: Iran, Syria and in a certain sense Qatar. Revolutions of the first months of 2011 introduced a large uncertainty about the future. Hamas leaders demanded immediate and unconditional opening of borders to Gaza and claimed that they could offer Israel limited hudna and the ceasefire. According to the leader of Hamas in Gaza, Yusuf Ashrafi: "We do not fight for the food supply, but the al-Aqsa mosque" 85 .

80 Israel and Hamas, An end to the fighting, Jan 18th 2009 | JERUSALEMFrom Economist. com, Israel and Hamas call separate ceasefires in their war in the Gaza Strip, http://www.economist.com/world/mideastafrica/displayStory.cfm?story_id=12959944\&source=features_box_main, 28.02.2015.

81 Ibidem.

82 "This is our victory image", wrote Yossi Sarid - the former leader of Meretz. Ibidem.

83 These values are compared to the British losses as a result of German thrust in World War II. Diplomacy after the Gaza war, Now get back to making peace, Jan 22nd 2009 | CAIROFrom The Economist print edition, But the battle has deepened the bitter divisions between the Arabs, as well as between the Palestinians and Israel.

84 King of Saudi Arabia Abdullah on Arabic summit in Kuwait warned, „internal Palestinian divisions are more dangerous than Israel." Cited from: ibidem.

85 It is located in Jerusalem, the third holiest site for Muslims, ibidem. 
You can notice a great diplomatic activity mainly in Egypt from 18 January 2009 (the date of cease-fire), but also Saudi Arabia and Qatar. The revolution in Egypt in 2011 reduced the diplomatic skills of Cairo. You can even ask the question: What was the real dimension of Israel's war with the Palestinians? Could it turn into a long-term, pathological war crisis? ${ }^{86}$ Only IDF generals headed by Yoav Galant, commander of operations in the Gaza Strip, are optimists. UN agencies estimate that during the threeweek war in the Gaza Strip 4,100 houses were destroyed and 15,000 damaged. During air raids 50000 people found shelter in schools and other public buildings. In May 2009, thousands of Palestinians from the bombed areas still lived only in tents in the camps. You can not see the signs of recovery. International donor conference in Sharm El Sheikh in Egypt pledged \$ 4.5 billion aid in March ${ }^{87}$.

The dynamics of proliferation of terrorist structures is very high, and their goals far extremist. The oriental civilization is becoming multipolar. The creation of the so-called Jihad State on the part of the Iraqi-Syrian territory based on Sunni groups is a challenge not only for Israel but also for structures with Shiite Iran at the helm. Prime Minister Benjamin Netanyahu's optimism assuming secure Israel in its functioning, who on 16 January 2015, after the shooting in front of a synagogue in Copenhagen, called on the Jews of Europe to return to Israel, was challenged by the Chief Rabbi of Denmark, who expressed the view that their place is not the Jewish state, but Europe.

\section{II.3. Fatahland in the Israeli political and military strategy in the context of the diplomatic efforts of the United States}

On 18 and 19 May 2009, Prime Minister Benjamin Netanyahu was in Washington and it was the first visit since the two leaders of the US and Israel took power in their countries $^{88}$. President Barack Obama focused mainly on Iran, because it is the main problem

86 According to H. Sapphire, some people see features of modern Hundred Years' War in it. Ibidem, p. 93.

87 The Gaza Strip, Not nearly back to normal, Apr 30th 2009| GAZA CITY, From The Economist print editionThree months after Israel's war ended, life for Gazans is still dismal, http://www. economist.com/world/mideast-africa/displaystory.cfm?story_id=13578934, 28.02.2015.

88 Jerusalem (PAP/Reuters, AFP,AP). Last visit is full of controversies - US President Barack Obama met with Israeli Prime Minister Benjamin Netanyahu when the latter in March 2015 came to Washington at the invitation of the Republicans to give a speech before the joint session of Congress. A spokesperson for the National Security Council at the White House Bernadette Meehan explained that according to the „long-standing practice and principles," the president does not meet with the leaders of countries where the elections soon to be held or with candidates in the election. She noted that it was to avoid suspicion of trying to influence the elections. The US Secretary of State John Kerry did not meet with Netanyahu either. A day earlier, Kerry expressed regret that the leader of the House of Representatives, Republican John Boehner had acted in a manner contrary to diplomatic protocol, and he learned of the initiative to invite Netanyahu from the message that Boehner had given. See: http://wyborcza.pl/1,91446,17297811,Obama_nie_spotka_sie_z_Netanjahu_podczas_jego_wizyty.html\#ixzz3SrIdoICW, 28.02.2015. 
for Israel. With the same force, they accentuated the Israeli-Palestinian standardization and stabilizing peace process. Many inaccuracies appeared in the case of a two-state settlement. During the visit, Prime Minister Benjamin Netanyahu informed on Israel's possible self-defense in the context of the threat from Iran ${ }^{89}$. The issue analyzed in parallel is a problem of the standardization process with the Palestinians. If there is relationship between the problems, said Barack Obama, it will develop in a different way than it is usually believed. To the extent that we can make peace with the Palestinians, said the president, we will strengthen ourselves in the international community in settling things of the threat from Iran ${ }^{90}$. The price of US involvement in the process of stabilizing peace in the subregion Palestine is high, the chance to settle in the best case are mixed, and all the actions appear to be extremely risky. Awkwardness of G. W. Bush's policy was based on the fact that he destroyed at the same time the role of the modernists among Israelis and Palestinians, and heavily reduced the brokerage function of the US administration ${ }^{91}$.

The conflict is very difficult. Moreover, history and culture complicated decisionmaking and strategic choices made by the two nations. Their experiences in the twentieth century were very different, but both nations were left with a fractional divided national consciousness and with very weak institutions to incorporate decisions in life. For the Israelis determining the relationship between religion, ethnicity and nationality was and is an extremely difficult problem. Among the questions to be put there must be the one referring to the nature of return of the Jewish population to the Middle East, whether it was secular with religious tinge, like among many independence goals in other movements? Or maybe it was the fundamentalist-religious project?92 Israel is the Jewish state on the international scene. Another problem lies in the fact that although the Israelis are a young nation, the Jews belong to the category of a very old nation. Jews came from different regions and cultures and their expectations in Palestine were very diverse. Israeli society survived traumatization as a result of the Holocaust and the collapse of the idea and practice of assimilation. In Palestine, they experienced the threat of destruction. The situation of the Palestinians is surprisingly similar. Palestinian nationalism underwent oscillation between the secular and the re-

89 "Israel reserves the right to act in self-defence." America grapples with Israel, What did Barack Obama truly feel? May 21st 2009 | WASHINGTON, DC, From The Economist print edition, America's president fails to reassure Israel's prime minister, http://www.economist.com/world/ mideast-africa/displaystory.cfm?story_id=13701719, 28.02.2015.

90 Ibidem, Israeli prime minister also held talks with $\mathrm{H}$. Clinton, the Secretary of State and James Jones, the United States National Security Advisor.

91 See: W.R.Mead, Change They Can Believe In. To Make Israel Safe, Give Palestinians Their Due, „Foreign Affairs”, January/February 2009, vol. 88, No 1, p. 59.

92 Ibidem, p. 61. 
ligious direction. Do Palestinians differ from other Muslims and even Christians? Are they part of a global ummah (Muslim community)?

The national identity of the Palestinians and a common history give a stronger expression than in other Muslim nations. Levant was subject to strong diversification, especially in the nineteenth century. Christians, Druze, Jews accounted for $20 \%$ of the population. Jerusalem, with the majority of the Christian and Jewish population, had different cultural characteristics. In the twentieth century, Palestine experienced large turbulence. The tragic division of Palestinians into Hamastan in Gaza and Fatahstan in the West Bank is an expression of splitting the Palestinian national policy and embodies its institutional fragility ${ }^{93}$. Palestinians in Jordan, Syria and Lebanon will be the most important group of voters when the state is created and security guarantees for Israel must be given as well. The interests of the group may be different from the aspirations of the Palestinians of the PA and nobody knows who would participate in the negotiations on their part representing their values and goals. In the twentieth century, the policy of the international community towards Palestine was cynical and brutal, and both ethnic groups were basically betrayed by it. Both entities: Palestinians and Jews trusted their own instincts more than single powers.

The most serious challenge for the US administration is favoring Israel for decades. Regulations relating to borders, security, refugees, access to water intakes are well understood by the parties and the Obama administration can not alter the issues ${ }^{94}$. A historic opportunity for the Obama administration lies in addressing the elements of the strategy of the peace process for the Palestinians, without neglecting the interests of Israel. Neither an agreement nor a permanent occupation of the West Bank can give security to Israel. The agreement that will not result in a uniform support among Palestinians, will not improve the current situation of Israel. It follows that the system must contain elements relating to refugees, who are the source of increasing nationalism and legitimacy in Palestinian politics ${ }^{95}$. The compromise is to eliminate the zerosum goals, although most of the problems come down to a dangerous logic, in which Israel's victory means the defeat of the Palestinians. Conflicts involving the pursuit of actors in the region to change the intensity of activity in the implementation of certain values in their opponents become susceptible to peace regulations only when these aspirations, interests and values contained in them are flexible to change ${ }^{96}$. This flexibility of values in the conflict is crucial for the implementation of the peace procedures and for the beginning of reconciliation. It is very important that the president of the United

93 W.R. Mead, Change..., p. 63.

94 Ibidem, p. 65.

95 Ibidem, p. 68.

96 See: B. Meibar, Political Culture, Foreign Policy and Conflict. The Palestine Area Conflict System, Westport-Connecticut-London 1982, p. 72. 
States of America declares its commitment to the idea of an independent Palestinian State, but finds all the evil that the Palestinians have had to endure and announces compensation for the harm ensuring a future full of dignity for every Palestinian family. The Obama administration and the next ones should begin consultations with different groups from the Palestinian Authority in order to determine their aspirations making recommendations on the United States concrete proposals addressing the key problems of this population.

Palestinians expect the peace to recognize the injustice that they have experienced, mainly as a result of the exodus of the Palestinians after the war and subsequent clashes. Today it is a problem largely of financial compensations, which the Group Aix composed of economists and politicians from Israel, the Palestinians and the international personalities, estimates at \$55-85 billion ${ }^{97}$. Although the recognition and payment of compensations requires complex procedures and even the payment of compensations will be part of the final and comprehensive regulations, the demands in this matter should be analyzed during the negotiations. This will be the proof for the Palestinians, that justice is being implemented and peaceful solutions have consequences in the specific benefits of redress ${ }^{98}$. The right to return is a hard problem of the strategy of zerosum interactions of Israel with the PA, it may suggest that it is to eliminate the other side of the game ${ }^{99}$. It seems that the idea of a two-state solution excludes the return of 5 million Palestinians because they would be in a majority in the State of Israel. The US and the international community should facilitate the Palestinians to take the right decisions. Refugees and their families and heirs should be given several options of arrangements to choose from ${ }^{100}$.

The Obama administration should also propose a solution to the issue of the structural imbalance of the peace process. Palestinians in exchange for recognition of Israel, its high indigenous value, will be given at the beginning only the right to participate in the talks. It seems that in the final phase the cards should be reversed. That Israel will have to make concessions: withdrawal from the administered lands, elimination of settlements, military outposts, and the recognition of the Palestinian state. Palestinians at the end will also have to confront the difficult choices: to negotiate the right to return and approve options of the course of borders, variously assessed by Palestinian groups. Experiences from the Clinton administration period show that the imbalance had serious and negative consequences for the region. The US focusing on the Palestinians does not necessarily mean a departure from the interests of Israel. In addition, Netanyahu's

97 Data cited from: ibidem, p. 71.

98 Ibidem, p. 72.

99 See: B. Meibar, op. cit., p. 72.

100 W.R. Mead, Change..., p. 73. 
visit in March 2015 in the US Congress in an unfortunate pre-election period in Israel (Knesset elections were held on 17 March 2015), does not mean that the Obama administration will stop properly perceive interests of the State of Israel in the context of its security. Israel's security next to ethical and historical reasons related to the Holocaust is crucial in the US thinking on the Middle East region.

The Obama administration's insistence upon the stabilization means long-term benefits for Israel. At the same time making the Palestinian commitment to peaceful coexistence the key test for the peace process, the Obama administration focuses its analysis on the areas where most Israelis feel to belong. Always in the initial stages of the peace process, activities should focus on three main areas: 1 ) testing their own ideas in the context of the existing political reality, here President Obama's accents are new, and the political realities have been designated by the three-week war of Israel with Hamas in the Palestinian Territories where 1.5 million Palestinians lived, but now the amount has significantly decreased, and the details are not known; 2) the creation of a political contract on mutual commitments - it is a well conscious action of the US leadership; 3) make political negotiations auspicious ${ }^{101}$. In general, the system of these preliminary phases consists of various elements defining political issues and creating a climate of commitment to regulating negotiations. Maybe President Barack Obama's stay in the Middle East and his speech addressed to Muslims, and delivered on 4 June 2009 in Cairo, created a new climate in relations between the US and the world of Islam $^{102}$. Elimination of prejudices is a phenomenon much more important than the process of diplomatic negotiations.

The statistics show the size of the problem. 500 thousand Israeli settlers live in the West Bank, including East Jerusalem annexed in 1967. Out of 305 thousand settlers from the West Bank, up to 230 thousand live in large blocks. In addition, among them there are one hundred thousand ultra-Orthodox Jews living in two expanding border settlements: Beitar Ilit and Modin Ilit $^{103}$. Mitchell's mission caused that B. Netanyahu agreed to stop the construction of settlements in the West Bank, at least for a period of six months, with the exception of schools and public buildings. Prime Minister refused to put in the plan 2,500 units, mostly large blocks. The Obama administration suggested that the pro-American Arab states should show kindness to Israel in the development of trade, tourism and other business ventures. The Jewish settlement is

101 See: H.H. Saunders, The Othes Walls..., pp. 21-38.

102 Barack Obama speaks to the Muslim world, Let's be friends, Jun 4th 2009 | CAIROFrom The Economist print edition, America's president used his oratory to superb effect. Now for the hard part http://www.economist.com/world/mideast-africa/displaystory.cfm?story_id=13802957, 28.02.2015.

103 Israel does not recognize the inhabitants of Jerusalem as the settlers due to the Act of Annexation, hence the statistics always reduce the overall rate of about 200 thousand. Ibidem. 
the key to build governance in the Middle East. Its standardization, domestication and reduction can be one of the hardest issues to settle.

This raises the problem whether we are dealing with obsession associated with the construction of new settlements in the West Bank, or are the reasons for the perception of a threat to the Palestinians and the governance of the Middle East? ${ }^{104}$ The answer can be synthesized in such a way: daily violence used against Palestinians and their property in the West Bank by the IDF soldiers brings terrible damage to their morale - stationing of IDF soldiers and settlers in the areas of building settlements causes depletion and leads to the ruins of these areas. NGO Breaking the Silence formulated such requests, based on dozens of interviews with IDF soldiers ${ }^{105}$. Such thinking may have a weakness of simplification, because on these areas there are active Islamic extremists who use terrorist techniques, and one can not be passive. Other analysts note that Jewish settlers are not uniform structures, but they have been deeply divided over a century, and the border runs between the Zionist-oriented population and religious, Orthodox Jews. The population of religious Jews is from $1 / 3$ to $1 / 2$ of settlers in the West Bank, so 100 to 130 thousand residents, or $2 \%$ of the Jewish population of Israel ${ }^{106}$. Jews have built their settlement in the West Bank in places where they lived even before 1948, and therefore they reactivated their historical presence. The settlement and the creation of Israel in 1948 were the work of Zionism, while the West Bank is a symbol of the Bible. Hebron is a holy place for religious Jews where the patriarchs Abraham, Isaac, Jacob, and also outstanding for their religion women Sarah, Rebecca were buried. Rachel's tomb in Bethlehem and Joseph's in Nablus ${ }^{107}$. In the political thought of the Jewish community there is a clash of two trends: the Zionist mainstream aimed at the political independence of the Jews in the form of a democratic state and the religious movement to which Eretz Israel (Land of Israel) is central to the Jewish project. For the first the state Zionism seeks to expand settlements for the construction of sovereignty, the sovereignty of others is a means for the settlement of the land ${ }^{108}$. Judea and Samaria play a role in the defense system of Israel in the event of re-attack from the Islamic East. Many forces in Israel realize that keeping Judea and Samaria within Israel

104 See: Occupation of the Territories: Israeli Soldiers Testimonies 2000-2010. By Breaking the Silence, p. 431, http://www.ngo-monitor.org/pdf/bts_book2011.pdf, 12.03.2015.

105 Elliot Abrams refers very critically to these claims in his review: The Settlement Obsession. Both Israel and the United States Miss the Obstacles to Peace, „Foreign Affairs”, July/August 2011, No 4, vol. 90, pp. 142-152.

106 See: G. Taub, The Settlers: And the Struggle Over the Meaning of Zionism, Yale 2010, 240 pp. Cit. from: ibidem, p. 144 and following. Author of the monograph is a professor at Hebrew University in Jerusalem.

107 E. Abrams: The Settlement Obsession..., p. 147.

108 G. Taub, The Settlers: And the Struggle Over the Meaning of Zionism..., G. Taub's views cited from: E. Abrams, The Settlement Obsession..., p. 147. 
based on incorporation harm the state security. Against this background, Ariel Sharon broke up in the recent past from the extreme right, forming a centrist party Kadima. According to him, Zionism requires a Jewish majority in Israel. Hence, they should give up part of the territory of Greater Israel ${ }^{109}$. Even hypothetically realized in the future the vision of Greater Israel, from the Jordan to the Mediterranean, will be rather more of a burden for the political system and society than its advantage ${ }^{110}$. Actions aimed at the construction of Jewish settlements in the multi-million Arab-Palestinian environment do not reproduce Zionism, but increase diaspora - an isolated and marginalized minority ${ }^{111}$. Implementation of a democratic Jewish state requires separation from the 2.5 million Arab population living in the West Bank. Israel must continue, according to the center-leftist circles, the strategy commenced from the construction of the wall in 2003 and the withdrawal of settlements from Gaza in 2005. Hence, the most important is the peace process leading to a two-state solution.

Palestine in the new geopolitics has clear limits, even among supporters of peace with Israel and with Israel's help, and the community oriented to Persian Gulf and oil sheikdoms. On the other hand, modern Israel, the state of the turn of the first and second decade of the twenty-first century is a structure built on ideological foundations of rational messianism, because Zionism had such a form. Perhaps at the beginning of the twenty-first century it should be considered as the main center of Jewish population in the world ${ }^{112}$. The state was built with the support of many other nations, mainly the US. In addition to ensuring the security of the Jewish population in their own country after the tragic events related to the Holocaust, the United States were guided by US security interests, treating Israel as one of the best of their own investments in the creation of an international pro-American order.

Today it is already known that the efforts of only the United States are not enough and other entities, including the European Union, have to join the peace building process $^{113}$. Europe must primarily engage in the state-building process of the Palestinians. Two-state solution, as once Javier Solana emphasized, would create safety not only for the Middle East, but also for Europe itself ${ }^{114}$. So far, beside the financial assistance, the EU has produced only a statement of the need to end Israeli-Palestinian conflict. Nobody in either Israel or the Palestinian Authority believes that Europe can be

109 Ibidem, p. 148.

110 Ibidem.

111 Ibidem, p. 149.

112 S. Weiss tends indirectly for such an opinion: S. Weiss, Mój i nasz Izrael, „Wprost”, 4 .05.2008, No 18, p. 102. According to the author, 5.5 million Jews live in Israel and 7.5 in diaspora.

113 See: R. Miller, Europe's Palestine Problem. Making Sure the EU Matters to Middle East Peace, „Foreign Affairs”, September/October 2011, vol. 90, No 5, pp. 8-12.

114 Ibidem, p. 9. 
a better mediator and creator of the peace process than the United States. Europe because of geography, history, culture and commerce is more predestined to be involved in the Middle East than other actors. By focusing more on the state-building process for the Palestinians than on the negotiations, one can eliminate the friction between Washington and Brussels ${ }^{115}$. It is no longer just a further approach of Israel to the whole West but the Arab world as well.

Hence, the Palestinian state-building strategy is so important, which by consensus must be recognized by the entire area of the political scene of Israel. The first initiative of M. Abbas in 2011 to make the Palestinian Authority become the subject of a sovereign state and a full member of the United Nations meant the strategic shift in relation to the conflict with Israel. Abbas did not want to support the dying peace process, but to protect the existence of the system of omitting or rather bypass it by building Palestinian statehood. However, the Palestinian leaders M. Abbas and S. Fajjed ${ }^{116}$ had a shaky position in the Palestinian system and their fate depended both on the effectiveness of the peace and state-building processes.

The situation is difficult because after two decades of Israeli-Palestinian negotiations Palestinian national and state aspirations are not implemented, institutions of Fatahland have been very weakened by Israel, and Israeli settlers are rapidly increasing ${ }^{117}$. The initiative of the Autonomy at the UN does not mean that the Palestinians want to get the status of a sovereign state, but that they want to gain full membership in the world system as existing independent state, because at the beginning of January 2013, President Mahmoud Abbas renamed the Palestinian Authority for the State of Palestine with his decree $^{118}$. Earlier, at the end of November 2012 the Palestinian Authority was granted the status of „non-member observer state” in the United Nations ${ }^{119}$. On 17 December 2014 the European Parliament adopted a resolution recognizing „in principle” the Palestinian statehood. The resolution number RC8-0277 / 2014 was adopted ${ }^{120}$, and the European countries expressed the view that the aim was to boost the peace process. According to M. Abbas, and these are unofficial data, 134 countries have recognized Palestinian statehood.

115 Ibidem, p. 12.

116 S. Fajjed represented the group Third Way and was regarded as an outstanding economist and technocrat. Rami Hamd Allah took the office as prime minister on 6 June 2013 and belongs just as M. Abbas to al-Fatah.

117 See: K. Elgindy, Palestine Goes to the UN. Understanding the New Statehood Strategy, „Foreign Affairs", September/October 2011, vol. 90, No 5, pp. 102, 104.

118 Palestinian Authority officially changes name to 'State of Palestine', „Haaretz”, Saturday, May 02, 2015, Iyyar 13, 5775.

119139 countries were „for”, 8 ,against” and „41” (including Poland) abstained.

120 RC8-0277/2014, Resolutions: Recognition of Palestine statehood, http://www.europarl. europa.eu/news/pl/news-room/content/20141212IPR01105/html/Rezolucja-Parlamentu-Europejskiego-w-sprawie-uznania-pa\%C5\%84stwowo\%C5\%9Bci-Palestyny, 23.03.2015. 
This is certainly the success of the Palestinians and the significant rapprochement of the new state of the Palestinians to the international community - including the West. In the end, it is not the state recognition that determines its creation, but the historical process through which institutions and national consciousness are conditioned. Israel under the leadership of B. Netanyahu is stiffening their position and moving away from the concept of a two-state solution in Palestine. Such a deep crisis reflects the strategy of denial and can affect the dynamics of the unrest in the Gaza Strip.

The source of the crisis in the region of the Near and Middle East and the war confrontations were conflicting interests, but mainly their pathological perception - full of stereotypes, prejudice and hatred ${ }^{121}$. The original source of the crisis was a structural violence - poverty, which developed under the occupation of Israel in Palestine and particularly in the Gaza Strip. Israel is experiencing big problems in the implementation of care function of the state, which has been effectively dismantled by the subsequent governments. Analysts are asking themselves whether war with Hamas in Gaza could be an attempt of the total negation of the opponent and the indigenous system of its values. Everything indicates that it had the same countenance as the war in 1967. It was an asymmetrical confrontation and therefore unacceptable, and yet it existed giving bad testimony to the aggressors: Israeli cabinet and Hamas leadership. The international community did not pass the exam either. The decision-making elites on both sides of the conflict proved to be oriented extremist and approaching the subject of the dispute in an intransigent manner. Hatred in mutual attitudes was recorded for the next decades. Co-operative actions have little chance to pave a place in the Israeli-Palestinian interactions. In an environment of tension that are inherent contradictions $^{122}$ Israel chooses a strategy based on reducing the significance of the Palestinian opponent (Hamas) and the total transformation of its system of values. It is also a strategy of full negation of Hamas, an organization recognized as terrorist in the West, but also for the mass movement. The perception of high risk causes tension and this tension is not elementary, but increased and high. This situation can be contrasted with the potential integration processes and development strategies.

121 Perception of reality is associated with the issue of objective and subjective nature of international security. See: M. Pietraś, Bezpieczeństwo międzynarodowe (Ch. 14) [in:] Międzynarodowe stosunki polityczne, M. Pietraś (edit.), Lublin 2006, p. 325.

122 Extensive analysis on the environmental issues of contradictions, see: Chapter X in: J. Kukułka, Zaspakajanie potrzeb i rozwiązywanie konfliktów w stosunkach międzynarodowych [in:] Stosunki międzynarodowe. Geneza, struktura, dynamika, E.Haliżak, R. Kuźniar (edit.), Warszawa 2001, pp. 243-259. 
Unfortunately, in the situation in which Israel integrates with difficulty with the countries of the Orient Middle East, it is the West, mainly the United States that can be blamed in many ways ${ }^{123}$.

One is looking for many solutions for this pathological situation. For some, it is a restrictive US policy toward Israel, which lacks even the Obama administration, according to others the system reconstruction and the creation in Israel a strong security office, responsive to the challenges and incentives which stem from the Israeli society. Patrick Tyler evaluated with great disapproval that military men decide on war, peace and politics in Israel.

Is this a feature of Israel, the state in the Orient, or the West Israel in the system of the Middle East? The world has changed a lot after 11 September 2001 and there has been a natural militarization at the expense of civil-democratic mechanisms. There are also environmentally-system negative mechanisms like the parliamentary system forcing the shaky coalitions and security establishment at the head of the IDF. Charles D. Freilich also lists the system pathologies characterizing the decision-making process in Israel, which include lack of planning, politicization, information flow, the big role of the Prime Minister who implements the objectives of the coalition, which are dynamized by the military establishment, frequent recourse to force, in situations where you can apply alternative measures ${ }^{124}$. This issue has been developed with deep roots of statehood since 1955, when David Ben-Gurion returned to the post of Prime Minister, beating Moshe Sharett, who replaced him briefly. Ben-Gurion's environment is the "hawks” disrespecting diplomatic efforts and the integration of Israel in the ArabIslamic environment. According to the diplomat and scholar Patrick Tyler, this is not the Arabs who are responsible for the prolonged conflict, but the Jewish state itself for the strategy of the war leading to regional hegemony instead of peace negotiations ${ }^{125}$. Since the 60s, the Israeli strategy has been seriously enhanced by the US military assistance. We should ask ourselves the question whether this policy has undermined the American or mainly Israeli interests. According to Tyler, Israel had peace leaders, mainly prime ministers such as Moshe Sharett, President Haim Weizmann, Levi Eshkol, and Golda Meir. All of them eventually lost in the setting of integration line with the Arabic environment. The old generation of the warfare party had its second-

123 See the review of: P. Tyler, Fortress Israel : The Inside Story of the Military Elite Run the Country - and Why They Can't Make Peace, Farrar 2012, and Ch.D. Freilicha, Zion's Dilemas: How Israel Makes National Security Policy, Cornell University Press 2012 - written by A. Benn, Israel's Warlords. How the Military Rules in War and Peace, „Foreign Affairs”, March/April 2013, vol. 92, No 2, pp. 164-169.

124 Cited from: ibidem, p. 165.

125 Ibidem, pp. 165-166. 
generation successors. Israel uses the means of war to reduce short-term costs of its strategy towards its neighbors. The quoted author emphasizes the hard line by the two terms of President Dwight Eisenhower, refusing rearming Israel, which forced Tel Aviv to withdraw from the Gaza Strip and Sinai in 1956. US committed a big mistake relying up to such an extent on Israel during the Cold War and in the fight against terrorism ${ }^{126}$. According to Freilich ${ }^{127}$, Israel had to use means of war, as civilian political leaders were incompetent in the field of security and were supported by the environments of generals. It was a narrow single-aspect policy, dictated by the military. Using the contemporary categories of the language of science, we should say that Israel has not mastered the art of multi strategy. IDF remains the power in spite of the fact that the demographic base of the army forces narrows, to which $1 / 3$ of the population (Arabs and Orthodox Jews) can not be classified ${ }^{128}$. The military did not always opt for military means. During the first intifada in 1987, chief of staff Dan Shomron was against repressions and military use. In addition, many soldiers and intelligence officers opted against Barak/ Netanyahu's strategy of pre-emptive strike on Iran (leaders from I. Rabin to M. Dagan belonged to them). The US President refrained Israeli attack on Iran, but was not able to build the peace, although next to the Framework Agreement, there may be the specific, precise and final arrangement in June 2015.

Israel should be their co-creator if it belongs to the Western civilization functioning in the Oriental system. The State of Israel reflects a bad experience from its short history after 1948, resulting from a hostile regional environment. Politics dominates in the Israeli system over the culture of strategic thinking, and for several decades in place of a flexible democracy, standing military bureaucracy has appeared with their non-creative reactions on the occurring challenges, followed by extremist nationalists of Russian origin after the collapse of the Soviet empire.

Israel's place in the structure of the Middle East region has established by its long existence, technological developments, unique culture constituting a hybrid of secular and religious solution at the same time, a place among the nations of the Western world. The opposite pole is the dynamic Islamic Orient, which is fighting for regional hegemony. The result remains a mystery. No predictions formulated in the twentieth century and referring to the future of short to medium term have worked so far.

126 P. Tyler, Fortress Israel: The Inside Story of the Military Elite Run the Country - and Why They Can't Make Peace, Farrar 2012; cited from: ibidem, p. 166.

127 Ch.D. Freilicha, Zion's Dilemas: How Israel Makes National Security Policy, Cornell University Press 2012; cit. from: ibidem, p. 167.

128 A. Benn's opinion, the author the review article, ibidem, p. 168. 


\section{Bibliography}

"Israel reserves the right to act in self-defence." America grapples with Israel, What did Barack Obama truly feel? May 21st 2009 | WASHINGTON, DC, From The Economist print edition, http://www.economist.com/world/mideastafrica/displaystory.cfm?story_id=13701719 [access: 27.12.2009].

According to 'Times", cited from: http://wiadomosci.wp.pl/kat,1356,title,Times-supertajny-izraelski-magazyn-rakiet-nuklearnych-w-zasiegu-rakiet-Hamasu,wid,10714161,wiadomosc.html?ticaid $=1740$ b [access: 2.01 .2009 ].

Benn A., Israel's Warlords. How the Military Rules in War and Peace, „Foreign Affairs”, March/ April 2013, vol. 92, No2.

Brichta A., The New Premier-Parliamentary System in Israel; especialy subsection: "The New Premier

Cohen A., Miller M., Bringing Israel's Bomb Out of the Basement, „Foreign Affairs”, September/ October 2010, vol. 89, No 5.

Cohen A., Miller M., Bringing Israel's Bomb Out of the Basement. Has Nuclear Ambiguity Outlived Its Shelf Life?, „Foreign Affairs”, September/October 2010, vol.89, No 5.

Cronin K., Why Counterterrorism Won't stop the Latest Jihadist Threat, „Foreign Affairs”, March/ April 2015, vol. 94, No 2.

Djerejian E.P., From Conflict Management to Conflict Resolution, „Foreign Affairs”, November/ Dec.2006, vol. 85. No 6.

Elgindy K., Palestine Goes to the UN. Understanding the New Statehood Strategy, „Foreign Affairs”, September/October 2011, vol. 90, No 5.

Elizur Y., Malkin L., The War within: Israel 's Ultra-Orthodox Threat to Democracy and the Nation, Overlook Press 2013.

Frei D., Handbook of Foreign Policy Analysis. Methods for Practical Application In Foreign Policy Planning and Bussiness Risk Assessment, Dordrecht 1989; cited from: Reginia Zacharski J., Strategia bezpieczeństwa narodowego: podejście zintegrowane, ch. 3, [in:] Strategia bezpieczeństwa narodowego Polski, J. Gryz (edit.), Warszawa 2013.

Freilicha Ch.D., Zion's Dilemas: How Israel Makes National Security Policy, Cornell University Press 2012.

Goldberg J., Lesser Israel. How Jewish Extremism Threatens Zionism, „Foreign Affairs”, July/.August 2013, vol. 92, No 4.

http://wyborcza.pl/1,91446,17297811,Obama_nie_spotka_sie_z_Netanjahu_podczas_jego_wizyty.html\#ixzz3SrIdoICW [access: 27.12.2009].

Huppert U.J., Izrael na rozdrożu, Łódź 2001.

Israel and Gaza,The air war continues, Dec 28th 2008 | JERUSALEM, From Economist.com, Israel continues its assault on the Gaza Strip, killing over 280 people, http://www.economist.com/ world/mideastafrica/displayStory.cfm?story_id=12844105\&source=features_box_main [access: 27.12.2009].

Israel and Hamas, An end to the fighting, Jan 18th 2009| JERUSALEMFrom Economist.com, Israel and Hamas call separate ceasefires in their war in the Gaza Strip http://www.economist.com/ world/mideastafrica/displayStory.cfm?story_id=12959944\&source=features_box_main [access: 27.12.2009].

Israel's war in Gaza, Gaza: the rights and wrongs, Dec 30th 2008, From The Economist print edition, http://www.economist.com/printedition/displayStory.cfm?Story_ID=12853965 [access: 27.12.2009].

J. Pawlicki's interview with Uri Hupperte, Newsweek Polska, on 15-21.12. 2014, No 51.

Jihad: it was a massacre - there will be retaliation, http://wiadomosci.wp.pl/gid,10700148,title,Gazaplonie,galeria.html?ticaid=17379 [access: 27.12.2009].

Keesing`s Record of World Events. Weekly Diary of World Events, ed. by R. East, Cambridge, 1992, No 6, p. 38945. 
Kukułka J., Zaspakajanie potrzeb i rozwiązywanie konfliktów w stosunkach międzynarodowych [in:] Stosunki międzynarodowe. Geneza, struktura, dynamika, E.Haliżak, R. Kuźniar (edit.),Warszawa 2001.

Mead W.R., Change They Can Believe In. To Make Israel Safe, Give Palestinians Their Due, „Foreign Affairs", January/February 2009, vol. 88, No 1.

Meibar B., Political Culture, Foreign Policy and Conflict. The Palestine Area Conflict System, Westport- Connecticut-London 1982.

Milewski P., Amerykańscy przyjaciele Izraela, „Newsweek”, 10/2015, 2-8.03.15.

Miller, Europe's Palestine Problem. Making Sure the EU Matters to Middle East Peace, „Foreign Affairs", September/October 2011, vol. 90, No 5.

Palestinian Authority officially changes name to 'State of Palestine', „Haaretz”, Saturday, May 02, 2015, Iyyar 13, 5775.

Parliamentary System”, „The Annals of the American Academy of Political and Social Science”, 01/1998; 555(1).

Pedahzura A., The Triumph of Israel's Radical Right, Oxford 2012.

Pietraś M., Bezpieczeństwo międzynarodowe (Ch. 14) [in:] Międzynarodowe stosunki polityczne, M. Pietraś (edit.), Lublin 2006.

Resolutions: Recognition of Palestine statehood, http://www.europarl.europa.eu/news/pl/newsroom/content/20141212IPR01105/html/Rezolucja-Parlamentu-Europejskiegow-sprawie-uznaniapa\%C5\%84stwowo\%C5\%9Bci-Palestyny[access: 27.12.2009].

Salem P., The Future of Lebanon, „Foreign Affairs”, November/December 2006.

Schiff Z., Israel's War with Iran, "Foreign Affairs" November/Dec. 2006, vol. 85, No 6.

Sterling J., Sidner S., Goulding N., CNNUpdated 1707 GMT (0107 HKT), http://edition.cnn.co$\mathrm{m} / 2013 / 01 / 22 /$ world/meast/israel-elections/index.html [access: 23.01.2015].

Szafir H. (z Jerozolimy), Koalicja czerwonego guzika. Tajna oś obronna Izraela z umiarkowanymi państwami arabskimi, "Wprost" 18.03.2007, No 11.

Szafir H., Obudzić Szarona, "Wprost” 3.09.2006, No 35.

Szatkowska P., Kultura polityczna Izraela; [in:] Państwo Izrael. Analiza politologiczno-prawna, E. Rudnik (edit.), Warszawa 2006.

Świeca J., Regionalne i globalne oddziaływania międzynarodowe w kryzysie bliskowschodnim (19471992), Katowice 1993.

Świeca J., Subregion Palestyny. W Poszukiwaniu strategii opartych na rzeczywistości, Katowice 2012.

Świeca J., Współczesne systemy demokratyczne, part I: Wybrane zagadnienia z problematyki wyborczejoraz makroananlizy systemowej w ujęciu porównawczym, Kielce 2003.

Taub G., The Settlers: And the Struggle Over the Meaning of Zionism, Yale University Press 2010.

The Gaza Strip, Not nearly back to normal, Apr 30th 2009 | GAZA CITY, From The Economist print edition, http://www.economist.com/world/mideast-africa/displaystory.cfm?story_id=13578934 [access: 27.12.2009].

The Settlement Obsession. Both Israel and the United States Miss the Obstacles to Peace, „Foreign Affairs", July/August 2011, No 4, vol. 90.

The truth about Iran nuclear deal, http://www.ncr-iran.org/en/?gclid=CIecw4KY5MQCFRHHtAodwV0AOQ [access: 5.04.2015].

Tyler P., Fortress Israel: The Inside Story of the Military Elite Run the Country - and Why They Can't Make Peace, Farrar 2012.

Tyler P., Fortress Israel: The Inside Story of the Military Elite Run the Country - and Why They Can't Make Peace, Farrar 2012.

United Nations Security Council Resolution 1559, (September 2, 2004), http://www.jewishvirtuallibrary.org/jsource/UN/unres1559.html [access: 19.03.2015].

United Nations Security Council Resolution 1559, (September 2, 2004), http://www.jewishvirtuallibrary.org/jsource/UN/unres1559.html [access: 19.03.2015].

United Nations Security Council Resolution 1701 (August 11, 2006), http://www.jewishvirtuallibrary.org/jsource/UN/unres1701.html [access: 19.03.2015]. 
United Nations Security Council Resolution 1701 (August 11, 2006), http://www.jewishvirtuallibrary.org/jsource/UN/unres1701.html [access: 19.03.2015].

United Nations Security Council Resolution 1860 , (January 8, 2009), http://www.jewishvirtuallibrary.org/jsource/UN/unres1860.html [access: 27.12.2009].

Weiss S., Mój i nasz Izrael, „Wprost”, 4 .05.2008, No 18.

\section{"Western" Israel in the system \\ of the oriental civilization}

ABSTRACT

The article concentrates on defining of the civilization creature of the state Israel on the Middle East scene and on conditionings belongings of Israel both to the western system as and the eastern oriental world. The author gets to the bottom of the dynamics of the evolution of the demographic matter states as and into his scene of party-political which determines the external strategy and the policy. Finds, with foundations of State created by David Ben Gurion, evidenced the double character of Israel: on one hand on the lay structure created by the Ashkenazic party Mapai and later Labor Party, and on the other hand on the strong presence of the religion and the synagogue to which one gave back civil cases. The promotion of Sephardim from the half of years 70., the height of the meaning of rightist Likud and small orthodox formations, caused that Israel more and more modern and technologically modernized, so western, had simultaneously stood up an oriental state, in compliance with a membership the regional and unstable authority which demanded religious coalition members that to rank. The work composition focus on facts concerning both the internal situation as and subregional, mostly in the collation context with Iran and his regional allies.

The author is convinced, with the civilization visage of regional actors, he most put on weight manifests itself within a period of crises and wars. Because many places devoted to the Lebanese war with Hezbollah in 2006 as and later with Hamas organization ( so called three-week) war. In them came to light opportunism political elites of Israel and minimalized strategic thinking. The work avoids prognoses even on nearest future. The author denies prognosing as the indispensable condition of the scientific correctness of the text.

\section{„Zachodni" Izrael w systemie orientalnej cywilizacji}

STRESZCZENIE

Artykuł koncentruje się na definiowaniu istoty cywilizacji państwa Izrael na Bliskim Wschodzie oraz kwestii przynależności Izraela zarówno do cywilizacji zachodniej, jak i wschodniej. Autor analizuje dynamikę demograficzną w państwie, a także na jego scenie partyjno-politycznej, co razem określa strategię polityki zewnętrznej. W fundamentach państwa stworzonych przez Davida Ben Guriona odnajduje podwójny charakter Izraela: $z$ jednej strony występują świeckie struktury stworzone przez aszkenazyjskie Mapai - a później Partię Pracy, a z drugiej strony mamy do czynienia z silną obecności religii w funkcjonowaniu państwa.

Wzrost znaczenia od połowy lat 70. Sefardyjczyków, duże znaczenie prawicowego Likudu i małych ortodoksyjnych formacji spowodowało, że Izrael - coraz bardziej nowoczesny i zmodernizowany technologicznie, więc zachodni, jednocześnie stawał się orientalny, tworząc regionalne niestabilne koalicje o podłożu religijnym. W pracy położono nacisk zarówno na analizę sytuacji wewnętrznej, jak i subregionalnej, głównie w kontekście konfrontacji z Iranem i jego regionalnymi sojusznikami.

Autor jest przekonany, że oblicze cywilizacji podmiotów regionalnych najwydatniej objawia się w okresie kryzysów i wojen, dlatego wiele miejsca poświęcono libańskiej wojnie z Hezbollahem w 2006 roku, a później z Hamasem. W nich wyszedł na jaw oportunizm elit politycznych Izraela i zminimalizowanie myślenia strategicznego. Praca unika prognoz nawet dla najbliższej przyszłości. Autor zaprzecza prognozowaniu jako nieodzownemu warunkowi poprawności naukowej tekstu. 